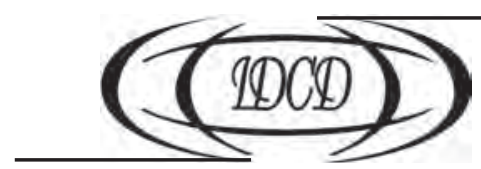

Doi: https://doi.org/10.15407/dse2017.01.132

УДК 331.2; 338.23

JEL CLASSIFICATION: J38

\title{
Г.С. ЛОПУШНЯК
}

д-р екон. наук, проф., проф.

ДВНЗ «Київський національний економічний університет ім. В. Гетьмана»

03680, Україна, Київ, проспект Перемоги, 54/1

E-mail: Lopushnyakgs@ukr.net

\section{МІНІМАЛЬНА ЗАРОБІТНА ПЛАТА: ПРАКТИКА УКРАЇНИ ТА ДОСВІД КРАЇН ЕВРОПЕЙСЬКОГО СОЮЗУ}

На основі компаративного аналізу мінімальної заробітної плати в Україні та країнах-членах Свропейського Союзу виявлено, що розмір цієї соціальної гарантії, навіть після підвищення, залишається одним із найнижчих серед аналізованих країн. Установлено, що в європейській практиці використовують три основних підходи до встановлення мінімальної заробітної плати, а саме: на основі мінімальних потреб працівника (цей підхід є притаманним і Украйні); на основі встановлення розміру, який у 2-2,5 рази перевищує прожситковий мінімум, і на основі співставлення розмірів мінімальної та середньої заробітної плати. Обгрунтовано, що протягом останніх років розмір мінімальної заробітної плати в Україні встановлювали із порушенням норм Закону «Про оплату праці». Акцентовано увагу на ризиках різкого підвищення розміру основної соціальної гарантії у сфері доходів (збільшення безробіття, переведення частини працівників на неповний робочий день, можллие збільшення неформальної зайнятості) $i$ визначено позитивні і негативні риси такого нововведення. Зокрема, до негативних віднесено: зміну змісту поняття «мінімальна заробітна плата» та поспішність ухвалення рішення щодо ї̈ підвищення. Враховуючи досвід країн-членів Свропейського Союзу подано пропозиції щодо зменшення негативного впливу від вищевказаних нововведень.

Ключові слова: мінімальна заробітна плата, посадовий оклад, прожитковий мінімум, середньомісячна заробітна плата.

\section{Г.С. Лопушняк}

д-р экон. наук, проф., проф.

ГВУЗ «Киевской национальный экономический

университет им. В. Гетьмана»

03680, Украина, Киев, проспект Победы, 54/1

E-mail: Lopushnyakgs@ukr.net 


\title{
МИНИМАЛЬНАЯ ЗАРАБОТНАЯ ПЛАТА: ПРАКТИКА УКРАИНЫ И ОПЫТ СТРАН ЕВРОПЕЙСКОГО СОЮЗА
}

\begin{abstract}
На основе сравнительного анализа минимальной заработной платы в Украине и странах-членах Европейского Союза выявлено, что размер этой социальной гарантии, даже после повышения, остается одним из самых низких среди анализируемых стран. Установлено, что в европейской практике используют три основных подхода к установлению минимальной заработной платы, а именно: на основе минимальных потребностей работника (этот подход присущ и Украине); на основе установления размера, который в 2-2,5 раза превышает прожиточный минимум, и на основе сопоставления размеров минимальной и средней заработной платы. Обосновано, ито в последние годы размер минимальной заработной платы в Украине устанавливали, нарушая нормы Закона «Об оплате труда». Акцентировано внимание на рисках резкого повышения размера основной социальной гарантии в сфере доходов (увеличение безработицы, перевод части работников на неполный рабочий день, возможное увеличение неформальной занятости) и определены позитивные и негативные черты такого нововведения. В частности, к негативным отнесены: изменение содержания понятия «минимальная заработная плата» и поспешность принятия решения о её повышении. С учетом опыта стран-членов Европейского Союза представлены предложения по уменьшению негативного влияния вышеуказанных нововведений.
\end{abstract}

Ключевые слова: минимальная заработная плата, должностной оклад, прожиточный минимум, среднемесячная заработная плата.

\section{G.S. Lopushnyak}

Dr. Sc. (Economics), Prof.

Vadym Hetman Kyiv National Economic University

03680, Ukraine, Kyiv, Prospect Peremogy, 54/1

E-mail: Lopushnyakgs@ukr.net

\section{THE MINIMUM WAGE: UKRAINIAN PRACTICE AND THE EXPERIENCE OF THE EUROPEAN UNION COUNTRIES}

Based on the comparative analysis of minimum wage in Ukraine and European Union countries it is revealed that the size of this social guarantee, even after increase, remains to be one of the lowest among the analyzed countries. It is established that in the European practice there are three main approaches concerning establishment of minimum wage, namely: on the basis of the minimum needs of the worker (this approach is also inherent to Ukraine); on the basis of established amount which by 2-2.5 times exceeds the living wage and on the basis of comparison of the sizes of the minimum and average salary. It is proven that in recent years the size of minimum wage in Ukraine has been established with the violation of the provisions of the Law «On compensation». The attention is focused on the risks of a sharp increase in the amount of the basic social guarantees in the sphere of income (increase of unemployment, transfer of part of employees to part-time work, possible increase of informal employment) and identifies the positives and negatives of such innovation. In particular, the negatives are: a change in the content of the concept of «minimum wage» and the haste when making decisions about its increase. Considering experience of member countries of the European Union propositions are given on reduction of negative impact of the above-stated innovations.

Keywords: minimum wage, official salary, living wage, average monthly salary.

Постановка проблеми. Проголосивши курс на євроінтеграцію, Україна задекларувала стратегічну мету - «досягнення європейських стандартів життя» [1], отже і забезпечення основних державних соціальних стандартів та гарантій на рівні країн Свропейського Союзу (ЕС). Однією з таких гарантій є мінімальна заробітна плата, яка застосовується як в Україні, так і в переважній більшості країн ЕС.

3 01.01.2017 р. в Україні відбулось різке підвищення розміру зазначеної соціальної гарантії та зміна змісту самого поняття «мінімальна заробітна плата», що спричинило чисельні дискусії щодо доцільності ухвалення такого рішення і його наслідків на низку соціально-економічних показників. Це актуалізувало проблематику дослідження. 
Аналіз досліджень. Питання мінімальної заробітної плати завжди були в центрі уваги науковців і практиків, оскільки ця соціальна гарантія впливає на низку показників соціально-економічного розвитку країни. Заслуговують на увагу результати дослідження групи авторів, висвітлені у монографії [2] за загальною редакцією А. Колота (А. Kolot) та Г. Кулікова (H. Kulykov), праці Е. Лібанової (Е. Libanova) [3], O. Мельниченка (O. Melnychenko) [4] та інших українських вчених. Вони розглядали мінімальну заробітну плату як засіб державного регулювання доходів населення, як основу для побудови тарифної сітки, досліджували наслідки запровадження диференціації мінімальної заробітної плати по видах економічної діяльності та ії̈ співвідношення з іншими соціальними стандартами та гарантіями. Практика встановлення мінімальної заробітної плати у країнах ЄС висвітлена у працях А. Камінської і П. Левандовського (A.Kamińska, P. Lewandowski) [5], Т. Шультена (T. Schultena) [6], Л. Функа і Х. Леша (L. Funka and H. Lescha) [7] та ін.

Проте надто низький розмір цієї соціальної гарантії в Україні порівняно з країнами $\mathrm{EC}$, незважаючи на підвищення, сприяє поширенню такого явища як бідність серед населення що працює, посилює міграційні процеси у напрямі виїзду за кордон висококваліфікованих спеціалістів та створює передумови для поширення утриманських настроїв серед населення. Зазначене зумовлює потребу у дослідженні окресленої проблематики.

Метою даної статтіє компаративний аналіз мінімальної заробітної плати в Україні та країнах ЄС для вивчення можливості впровадження європейського досвіду в українську практику, а також дослідження можливих наслідків впливу різкого підвищення зазначеної гарантії на доходи та зайнятість населення з розробкою відповідних пропозицій щодо зменшення негативних наслідків цього нововведення.

Виклад основного матеріалу. Схвалені зміни до чинного законодавства щодо змісту поняття «мінімальна заробітна плата» призвели до реформування системи оплати праці. Зокрема, нове визначення цього поняття вже не містить норми, що це плата за просту некваліфіковану працю, що вносить суттєві зміни у порядок формування тарифної сітки. Якщо раніше тарифна ставка робітника першого розряду, яка $є$ основою для формування тарифної сітки, повинна була встановлюватись «у розмірі, що перевищує законодавчо встановлений розмір мінімальної заробітної плати», то тепер «мінімальний посадовий оклад (тарифна ставка) встановлюється у розмірі, не меншому за прожитковий мінімум для працездатних осіб» [8, 9].

Такі зміни дозволяють штучно наблизити співвідношення мінімальної та середньої заробітної плати в Україні до європейських стандартів: у ЄС мінімальна заробітна плата становить 50-60 \% від середньомісячної. В Україні протягом 2010-2016 рр. намітилась тенденція до зниження вищезазначеного показника ( 45,35 \% у січні 2010 р. до 30,9 \% у грудні 2016 р.).

Теза про штучне наближення співвідношення мінімальної та середньомісячної заробітної плати до європейських стандартів підтверджується тим, що унаслідок зміни змісту самого поняття «мінімальна заробітна плата» та суттєвого заниження офіційно затвердженого прожиткового мінімуму (у грудні 2016 р. на 53,4 \%), розмір посадового окладу робітника першого тарифного розряду залишився удвічі нижчим від мінімального розміру заробітної плати, занизивши тим самим на 52 \% і посадові оклади працівників вищих тарифних розрядів.

Таким чином, підвищення з 01.01.2017 р. мінімальної заробітної плати до 3200 грн можна назвати індексацією цієї соціальної гарантії. Такий крок Уряду, незважаючи на масштабну критику цього рішення, є виправданим із точки зору 
соціального захисту працівників з найнижчою оплатою праці. Водночас, установлення посадового окладу першого тарифного розряду на рівні штучно заниженого прожиткового мінімуму, як вказано вище, не забезпечує диференціацію посадових окладів відповідно до професійного рівня і призводить до «зрівнялівки» в оплаті праці працівників 1-11 тарифного розрядів. Зміна змісту самого поняття «мінімальна заробітна плата» у поєднанні з необхідністю проведення доплати до мінімального рівня значній частині працівників призвела до нівелювання або зменшення ролі більшості мотиваційних чинників: премій, надбавок за високі досягнення у праці, за класність водіям автотранспортних засобів, доплати за виконання особливо важливої роботи на певний термін тощо.

Різке підвищення мінімальної заробітної плати можна виправдати і тим, що частка витрат на оплату праці у структурі операційних витрат діяльності підприємств, за даними Державної служби статистики України, у 2010-2015 рр. коливалась у межах 7,3-10\%. За даними Евростату, у країнах Західної Европи вона сягала до 45 \%. Така низька частка витрат на оплату праці в Україні свідчить про можливість значного підвищення заробітної плати працівникам без зростання ціни продукції.

Високий рівень бідності, у тому числі й серед працюючого населення, та значна частка соціальних трансфертів у структурі доходів громадян теж зумовлювали необхідність вищевказаного рішення, адже підвищення мінімальної заробітної плати є значно продуктивнішим методом боротьби з бідністю, ніж різноманітні форми соціальної допомоги.

Крім того, мінімальна заробітна плата в Україні, навіть після підвищення, залишається однією з найнижчих в Європі (рис. 1). Її купівельна спроможність є набагато нижчою, ніж в інших країнах. Так, за мінімальну заробітну плату в Україні можна купити 58 «борщових наборів», у Польщі - 185, а у Великій Британії - 230.

Найвищий рівень заробітної плати серед Свропейських країн зафіксовано в Люксембурзі, Монако, Бельгії, Ірландії та Нідердандах, що відповідає рівню економічно-соціального розвитку цих країн і свідчить про реалізацію у них концепту гідної праці в частині її оплати. Найменш захищеними цією соціальною гарантією $є$ наймані працівники Молдови. На початок 2017 р. мінімальна заробітна плата в цій країні становила 99 євро (у 2015 р. - 79 євро). Найнижчим у цій країні, порівняно з іншими країнами ЄС, є й обсяг ВВП на душу населення (у 2015 р. - 1851,2 дол. США). В Україні аналогічний показник становив 2115,0 дол. США, а мінімальна заробітна плата у 2015 р. - 51 євро.

Порівнюючи наведені вище показники, а саме ВВП на душу населення можна стверджувати, що підвищення мінімального рівня заробітної плати в Україні доцільно було здійснювати поступово (наприклад щоквартально) протягом попередніх двох років на 10-15\%, адже чим коротший інтервал між термінами коригування, тим більше зміна мінімальної заробітної плати буде відповідати зміні чинників, які на неї впливають. Сприяло цьому і зниження у 2016 р. навантаження на фонд оплати праці за рахунок зменшення ставки єдиного соціального внеску до 22 \% та відміна сплати цього внеску найманими працівниками. Проте у 2015-2016 рр. підвищення мінімальної заробітної плати було незначне - на 31,4 \% (з 1218 грн до 1600 грн).

Вважаємо, що найбільшої шкоди підприємцям було завдано не різким підвищенням мінімальної заробітної плати, а їхньою неготовністю до такого поспіхом ухваленого рішення. Крім того, збільшення розміру основної соціальної гарантії здійснено з порушенням п. 3. ст. 27 Бюджетного кодексу України та п. 4.1.9 ст. 4 Податкового кодексу України. Наближення мінімальної заробітної плати протягом 2017 р. до 


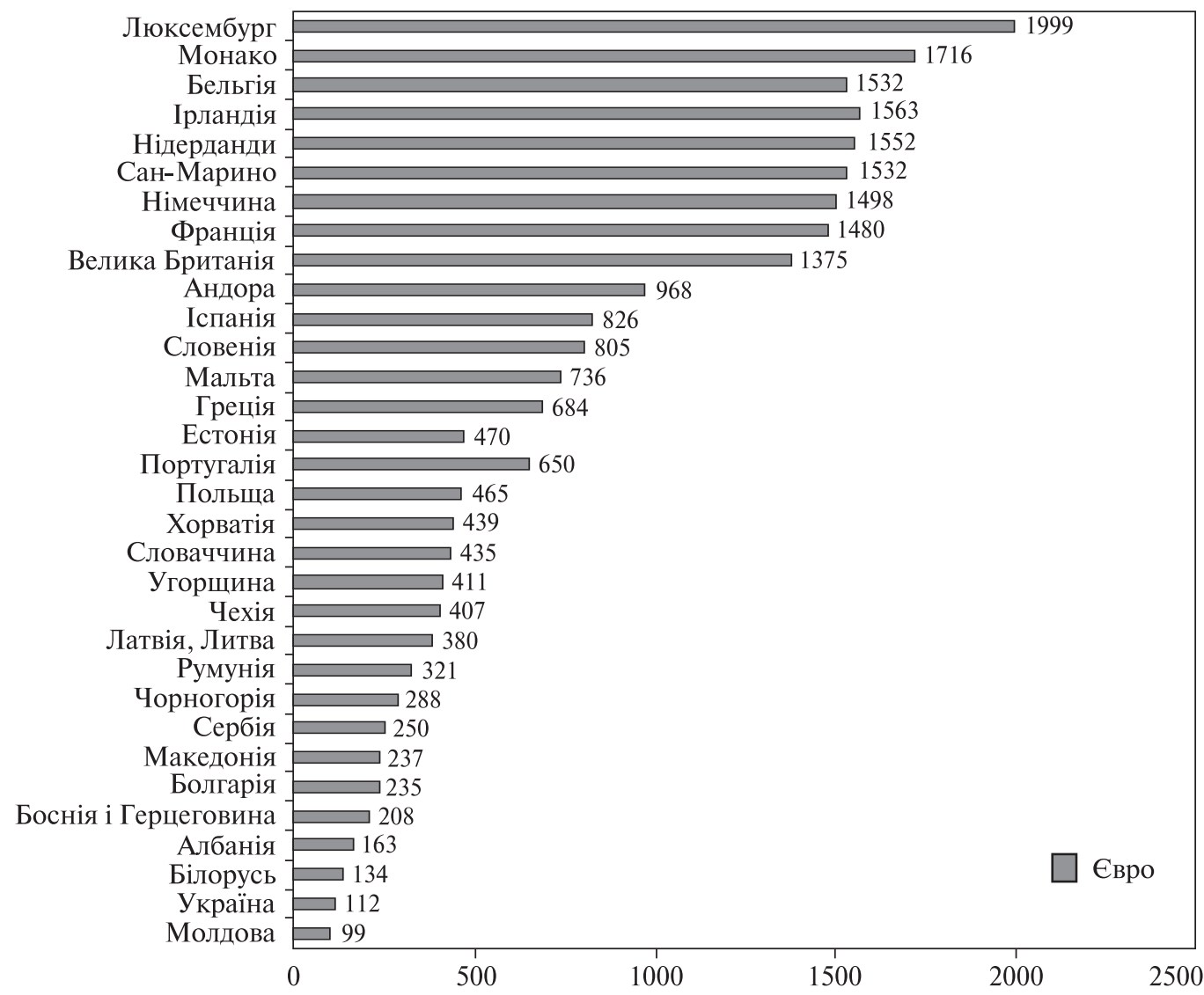

Рис. 1. Мінімальна заробітна плата в країнах Свропи (станом на 01.012017 р. *) у євро

* Греція (2012), Чорногорія (2014), Сан-Марино (2015), Боснія і Гецоговина, Андора, Монако, Македонія, Литва, Велика Британія (2016)

Джерело: Minimum wage statistics: Eurostat official information. URL: http://ec.europa.eu/eurostat/statistics-explained/index.php/Minimum_wage_statistics (Access mode 05.02.2017); Wages in the Principality: servise public du Gouvernement Princier de Monaco. URL: http://en.service-public-particuliers.gouv.mc/Employment/Employees/Contracts-and-pay/Wages-in-the-Principality (Access mode 05.02.2017); Bosnia's Serb Republic raises minimum wage by $6.8 \%$. SeeNews, Bosnia and Herzegovina. URL: https://seenews.com/news/bosnias-serb-republic-raises-minimum-wage-by-68-550726 (Access mode 05.02.2017); Germany raises the minimum wage by four percent in 2017. URL: http://www.globalupside.com/germany-raises-the-minimum-wage-by-four-percent-in-2017/ Global Upside, january 10,2017 (Access mode 05.02.2017); Minimum Wage Ireland 2017. URL: http://www.moneyguideireland.com/minimum-wage-ireland-2017.html Money Guide Ireland. (Access mode 05.02.2017). Про Державний бюджет України на 2017 рік: Закон України від 21.12.2016 № 1801-VII. URL :. http://zakon5.rada.gov.ua/laws/show/1801-19

розміру фактичного прожиткового мінімуму в декілька етапів (наприклад, 3 01.01.2017 p. - на $30 \%$ (2080 грн), з 01.04.2017 р. - на $30 \%$ (2704 грн), з 1.07.2017 р. на $30 \%$ (3515 грн) дало б можливість підприємцям скоригувати свої бізнес-плани, зменшити негативний вплив від різкого неочікуваного додаткового навантаження на витрати підприємств і дало змогу дослідити вплив зміни на інші показники.

За рекомендаціями МОП під час визначення рівня мінімальної заробітної плати потрібно враховувати не лише потреби працівників, а й їхніх сімей, а також «економічні чинники, в тому числі необхідні умови економічного розвитку, рівень продуктивності й бажаність досягнення та підтримання високого рівня зайнятості» [10]. 
Чинне законодавство України практично дублює рекомендацію МОП. Зокрема в Законі «Про оплату праці» зазначено, що «розмір мінімальної заробітної плати визначається з урахуванням потреб працівників та їхніх сімей, вартісної величини достатнього для забезпечення нормального функціонування організму працездатної людини, збереження iї здоров’я набору продуктів харчування, мінімального набору непродовольчих товарів та мінімального набору послуг, необхідних для задоволення основних соціальних і культурних потреб особистості, а також загального рівня середньої заробітної плати, продуктивності праці та рівня зайнятості» [8].

На жаль, попри різке підвищення з 01.01.2017 р., рівень мінімальної заробітної плати в Україні не повністю враховує навіть потреби самого працівника, не говорячи вже про його сім'ю, оскільки він є нижчим за фактичний прожитковий мінімум для працездатного населення, розрахований на одну особу за визначеною методикою. Крім того, оновлені у 2016 р. норми основних видів продуктів харчування, які враховуються у ході розрахунку прожиткового мінімуму, практично не змінилися з 2000 р., і не відповідають мінімальним потребам людини та реаліям життя (детальніше у [11]).

Вважаємо, що причиною такого стану є відсутність методики визначення мінімальної заробітної плати, що створює можливості для маніпулювання розміром цієї соціальної гарантії.

Загалом, у європейській практиці застосовуються три підходи до розрахунку мінімальної заробітної плати:

1) на основі мінімальних потреб працівника. За цим підходом розмір мінімальної заробітної плати визначається на основі прожиткового мінімуму (впроваджений в Україні). Проте вважають, що його доцільно використовувати лише у воєнний час;

2) на основі встановлення розміру, який у 2-2,5 рази перевищує прожитковий мінімум. У деяких країнах ці додаткові витрати враховують під час розрахунку споживчого кошика. Так, наприклад, у Великій Британії до нього включено 350 складових, серед яких: витрати на садівника, шампанське, пиво, акустичну гітару. У Франції у цьому наборі присутні послуги перукаря, придбання косметичних засобів, оренди автомобіля, таксі;

3) на основі співставлення розмірів мінімальної та середньої заробітної плати. Рекомендоване СС значення цього показника - 60 \%, а Міжнародною організацією праці (МОП) - $50 \%$.

Інститут мінімальної заробітної плати діє в 22 країнах ЄС. Водночас у Австрії, Данії, Італії, Кіпрі, Швеції та Фінляндії єдиний розмір мінімальної заробітної плати на законодавчому рівні не затверджується, проте існує практика укладання колективних угод між соціальними партнерами та затвердження зарплатного мінімуму для деяких професій. Зауважимо, що колективні угоди можуть мати і загальній обов’язковий характер. Наприклад, у Фінляндії громадська комісія при Міністерстві соціальних справ та охорони здоров'я, як правило, ухвалює рішення щодо обов'язкового виконання укладених колективних угод усіма роботодавцями [12]. На Кіпрі в результаті тривалих дискусій наприкінці 2015 р. досягнуто домовленостей щодо фіксації розміру мінімальної заробітної плати в колективному договорі у сфері металообробної промисловості.

У дев’ятьох країнах ЄС (Португалія, Словенія, Іспанія, Чехія, Польща, Греція, Словакія, Хорватія, Нідерданди) рівень мінімальної заробітної плати в односторонньому порядку визначає уряд. Незважаючи на це, в Ховатії, Португалії, Словенії та 
Іспанії для визначення мінімальної заробітної плати на 2016 р. були попередньо проведені консультації з соціальними партнерами, що свідчить про дієвість принципу соціального партнерства в цих країнах.

У Болгарії, Естонії, Латвії, Литві, Угорщині, Румунії, Німеччині, Ірландії, Великій Британії розмір мінімальної заробітної плати визначається урядом після необов'язкових рекомендацій соціальних партнерів. Так, в Угорщині відповідно до Трудового кодексу Кабінет Міністрів встановлює мінімальний розмір заробітної плати після консультацій з Національною економічною і соціальною радою. Уряд також проводить консультації з соціальними партнерами в рамках тристороннього постійного форуму роботодавців і працівників, проте рекомендації останніх не є обов'язковими. В Болгарії та Латвії роль консультативного органу відіграє національна рада з трьохстороннього співробітництва, в Естонії - Естонська конфедерація профспілок та конфедерація роботодавців.

Ще в чотирьох країнах ЄС (Бельгія, Люксембург, Мальта та Франція) визначення мінімальної заробітної плати відбувається відповідно зі встановленим правилом та на основі консультацій з соціальними партнерами. У цих країнах зазначена соціальна гарантія підлягає обов'язковій автоматичній індексації відповідно до індексу споживчих цін. У Франції ця норма діє у випадку підвищення споживчих цін більш як на $2 \%$. У Люксембурзі мінімальну заробітну плату коригують щоквартально відповідно до механізму індексації доходів громадян.

Таким чином, європейська практика свідчить, що рівень мінімальної заробітної плати є важливим індикатором не лише побудови системи гідної праці, а й соціально-економічного розвитку країни. Тому коригування іiі розміру має відбуватись із урахуванням зміни цін та загальних доходів населення з метою соціального захисту найменш оплачуваних працівників та забезпечення стабільності тарифної системи, зменшення ризику інфляційного тиску.

Проте в Україні не завжди виконується вимога щодо врахування економічних чинників. Так, під час розрахунків мінімальної заробітної плати практично не враховують поточний та прогнозний рівні зростання макропоказників української економіки. Зокрема, темп приросту мінімальної заробітної плати в деякі роки (2002, $2005,2010)$ значно перевищував темп приросту ВВП на душу населення. Найбільший розрив за прогнозними показниками буде у 2017 р. (рис. 2).

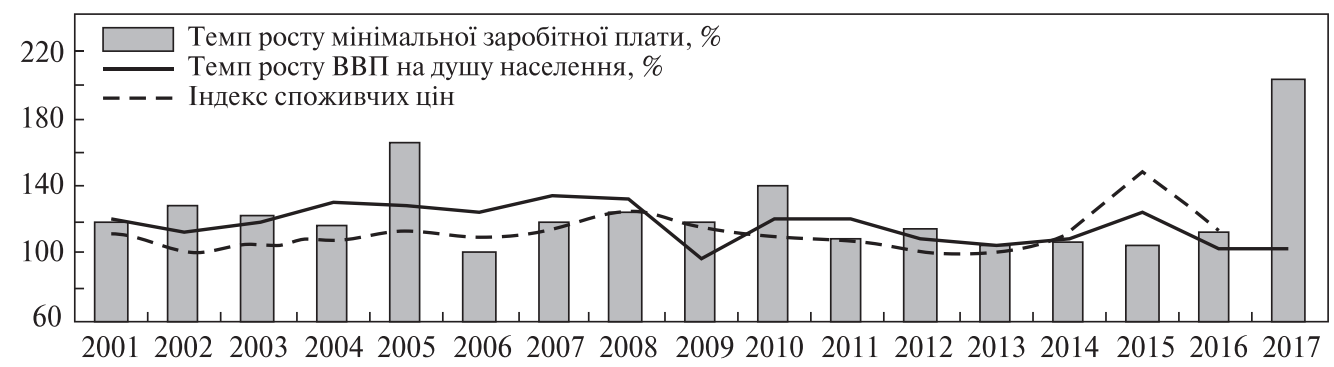

Рис. 2. Співвідношення темпів росту мінімальної заробітної плати, ВВП на душу населення і індексу споживчих цін у 2001-2017 pp.

Джерело: побудовано на основі розрахунків автора та статистичної інформації Державної служби статистики України. 
Таку ситуацію можна виправдати не надто високою часткою оплати праці у структурі ВВП (у 2002 р. - 44 \%; 2005 - 47,4, $2010-48,0,2015-39,1 \%$ ) і значним розривом у 2015 р. між підвищенням мінімальної заробітної плати та індексом інфляції. Проте, необгрунтовано різке підвищення зарплатного мінімуму без видимих ознак економічного зростання призводить до збільшення рівня безробіття, зростання цін і зниження купівельної спроможності населення.

Економічна теорія, підтверджена світовою та вітчизняною практикою, свідчить про те, що підвищення мінімальної заробітної плати може призвести як до збільшення доходів, у першу чергу, некваліфікованих робітників, так і до збільшення безробітних серед цієї категорії населення.

Практика ведення бізнесу в Україні свідчить, що під час чергових нововведень (особливо у вигляді «шокової терапії) п підприємці не поспішають виводити зарплати з тіні. Навпаки, на вимогу підвищити заробітну плату, вони вдаються до оформлення працівникам відпусток без збереження заробітної плати, переведення працівників на часткову зайнятість, офіційного скорочення їх із подальшим залученням до неформальної зайнятості.

Водночас, зважаючи на високий рівень тінізації економіки України (40 \% у 2015 р.; 35 - 2016), який є вагомою перешкодою на шляху становлення інституту гідної праці та економічного зростання, зниження у 2016 р. ставки єдиного соціального внеску та високий розмір штрафів за порушення трудового законодавства, підвищення мінімальної заробітної плати може спонукати роботодавців до виведення частини заробітної плати з тіні. Це дозволить збільшити надходження до бюджетів різних рівнів за рахунок податку з доходів фізичних осіб і зменшити дефіцит Пенсійного фонду України. Проте, одночасне збільшення безробіття призведе до додаткових витрат і нівелює ефект від можливих додаткових надходжень.

Висока ймовірність збільшення безробіття підтверджується і практикою інших країн. Наприклад, в Угорщині на початку 2001 та 2002 років уряд майже подвоїв заробітну плату (за два роки). У результаті відбулося значне зниження зайнятості. Особливо сильне скорочення кількості зайнятих зафіксовано у малому бізнесі. Також підвищення мінімальної заробітної плати призвело до зниження здатності залишитися на старому робочому місці або можливість знайти роботу для низькокваліфікованої категорії працівників [13]. Підвищення мінімальної заробітної плати мало найбільш негативний вплив на депресивні регіони Угорщини та низькокваліфіковану категорію працівників.

Останнє дослідження МВФ щодо країн центральної та східної Європи показало, що підвищення мінімальної заробітної плати на 10 \% збільшує безробіття на 0,4 \% [14]. За цією залежністю в Україні варто очікувати збільшення безробіття на 8 \%, тобто до 9,9 \%. Майже таким є прогноз Національного банку України: зайнятість скоротиться на 5 в. п. порівняно з 2016 роком, що відповідатиме 10 \% рівню безробіття (за методологією МОП). Також у інфляційному звіті регулятора зазначено, що зниження офіційної зайнятості буде непропорційним - більшою мірою відбудеться за рахунок збільшення кількості вивільнених працівників із малих і середніх підприємств і фізичних осіб-підприємців, що насамперед пояснюється майже двократним збільшенням податкового тиску на підприємства на єдиному податку. Частково таке зниження компенсується збільшенням неформальної зайнятості. Крім того, збільшення середнього рівня оплати праці в економіці може стимулювати повернення на ринок праці частини тих зневірених осіб, які почнуть пошуки роботи, та, як наслідок, рівень безробіття може додатково збільшитися [15]. 
Водночас, офіційні дані Державної служби зайнятості свідчать про зниження у січні-лютому 2017 року кількості зареєстрованих безробітних порівняно з аналогічним періодом 2016 року. Станом на 01.03.2017 р. цей показник менший на 13,6 \% (на 68,9 тис. осіб), ніж станом на 01.03.2016. У січні 2017 р. порівняно із груднем 2016 кількість зареєстрованих безробітних збільшилася на 9,8 \% (на 38,2 тис. осіб), а у лютому 2017 р. порівняно з січнем 2017 р. - ще на 2,4 \% (на 10,3 тис. осіб). Кількість осіб, які отримали статус безробітного у січні 2017 р., була на 17994 особи більше, ніж у січні 2016 р., середньомісячний розмір допомоги по безробіттю у лютому 2017 зменшився порівняно з січнем 2017 р. на 4,57 \% (на 92 грн), що може свідчити про звільнення у січні частини працівників із низьким рівнем оплати праці.

За результатами чергового щоквартального опитування керівників підприємств щодо поточної та майбутньої ділової активності, інфляційних і курсових очікувань, змін економічної ситуації в країні, яке було проведено з 8 листопада до 8 грудня 2016 року [16], відновились очікування респондентів щодо зменшення кількості працівників на своїх підприємствах у наступні 12 місяців. Баланс очікувань: $-4,3 \%$ (у III кварталі 2016 року -0,9\%. При цьому максимальне зменшення кількості працівників респонденти прогнозують на підприємствах сільського господарства (баланс відповідей $-25,0 \%$ ).

Не сприяє ефективній зайнятості і зростання необгрунтованої диференціації в оплаті праці на всіх рівнях. Зокрема, невиправданою є ситуація, коли мінімальна заробітна плата становить 3200 грн, заробітна плата професора більшості державних вищих навчальних закладів: 10-20 тис. грн, міністра відповідного міністерства: 20-120 тис. грн, а керівника державного підприємства - понад 1 млн грн. Така ситуація посилює тіньові тенденції на ринку праці. Вважаємо, що розмір оплати праці повинен базуватись на результативності роботи, мірі відповідальності, внеску у розвиток держави та забезпечувати диференціацію відповідно до професійного рівня, освіченості, досвіду та результатів роботи.

Таким чином, незважаючи на пожвавлення на ринку праці через умотивування безробітних до пошуку роботи (мінімальна заробітна плата у лютому 2017 р. більша від середньомісячної допомоги по безробіттю на 1277 грн), збільшення рівня безробіття в Україні до 10 \% (за методологією МОП) є цілком реальним, однак цю тезу можна буде підтвердити або спростувати лише за результатами першого півріччя. Адже для скорочення посади без порушення законодавства необхідно щонайменше два місяці, а бюджетні установи остаточні дані щодо фонду заробітної плати на 2017 рік отримали наприкінці лютого, тож затвердження штатної чисельності працівників відбулось не раніше лютого-березня 2017 р. і реальну кількість вивільнених працівників у зв'язку із підвищенням мінімальної заробітної плати ми зможемо дізнатись не раніше травня 2017 р. При цьому треба пам'ятати, що критичне значення рівня безробіття як індикатора економічної безпеки держави дорівнює $9 \%$ і його перевищення - пряма загроза не лише економічній, а й національній безпеці України. Тому одним із першочергових завдань Кабінету Міністрів України повинно бути напрацювання заходів, спрямованих на стимулювання зайнятості населення.

У Плані дій Уряду на 2017 рік не вказано чітких термінів виконання заходів у рамках забезпечення гідної праці в Україні, за винятком реформування Державної служби зайнятості (до 1 серпня 2017 р.) і створення на іiі базі Національного агенства зайнятості. Вважаємо, що в умовах обмеження фінансових ресурсів недоцільно змінювати назву відповідного державного органу, оскільки це зумовить додаткове навантаження на фонд оплати праці у зв'язку із вивільненням працівників та сприя- 
тиме можливості звільнення працівників з огляду не на професійну компетентність, а через ставлення керівництва. Розширення чи часткова зміна функцій державного органу можлива і без зміни його назви.

На відміну від активних дискусій щодо впливу підвищення мінімальної заробітної плати на рівень безробіття, сумнівів із приводу збільшення доходів населення унаслідок нововедення практично не виникає ні у кого. На нашу думку, суттєвого покращення добробуту населення не варто очікувати, бо суттєву зміну розміру основної соціальної гарантії варто назвати індексацією, а не підвищенням. Можна сказати, що Уряд виконав основне призначення мінімальної заробітної плати - захистив найменш оплачуваних працівників. Тому, в першу чергу, підвищення оплати праці стосуватиметься зазначеної категорії працівників. Це, з одного боку, дасть змогу вивести частину заробітної плати з «тіні», а з іншого змусить окремих підприємців скоротити кількість таких працівників чи перевести їх на неповний робочий день. У гіршому випадку - спонукатиме до неформальної зайнятості окремих працівників.

Залишається також проблемою оподаткування мінімальної заробітної плати, оскільки це суттєво занижує розмір отриманих доходів. Наприклад, під час нарахування заробітної плати у розмірі 3200 грн працівник отримає лише 2576 грн (18\% податок 3 доходів фізичних осіб і 1,5\% - військовий збір). Водночас, у більшості країн ЄС оподаткування заробітної плати мінімального розміру не здійснюється.

Виходячи з наведеного вище доходимо висновку, що в Україні визначення розміру мінімальної заробітної плати як однієї з основних соціальних гарантій відбувається із порушенням вимог Закону «Про оплату праці». Вважаємо, що визначати мінімальну заробітну плату потрібно не лише як основну державну соціальну гарантію, а й як фактор економічної безпеки країни, оскільки «невиправдано низький розмір заробітної плати, включаючи мінімальну, призводить до зниження продуктивності праці та споживчого попиту, падіння тривалості життя, підвищення рівня захворюваності населення та скорочення його чисельності, погіршення криміногенної ситуації, а також змушує громадян «сісти на голку» державних соціальних допомог та субсидій» [17, с. 10].

На жаль, серед індикаторів економічної безпеки немає жодного показника, пов’ язаного з мінімальною заробітною платою. Як індикатори економічної безпеки доцільно було б використовувати індекс Кейтца (відношення мінімальної заробітної плати до середньомісячної), відношення розміру посадового окладу (тарифної ставки) працівника першого тарифного розряду і відношення мінімальної заробітної плати до розміру прожиткового мінімуму.

Враховуючи викладене, можемо констатувати, що підвищення мінімальної заробітної плати в Україні до 3200 грн було необхідним кроком, оскільки внаслідок різкого збільшення тарифів на житлово-комунальні послуги та інші товари першої необхідності більшість працюючого населення не має змоги задовольнити власні мінімальні потреби. Це створює додаткове навантаження на бюджет: виплата допомоги малозабезпеченим, субсидії на відшкодування витрат на житлово-комунальні послуги тощо. Таке рішення необхідно було здійснювати поступово протягом року на основі проведення відповідних розрахунків і моделювання кількох варіантів розвитку подій із можливістю впроваджувати за необхідності відповідні стимулятори забезпечення гідної оплати праці та компенсатори можливих ризиків.

Висновки. На основі компаративного аналізу мінімальної заробітної плати в Україні та країнах-членах ЄС установлено, що розмір цієї соціальної гарантії в Україні залишається одним із найнижчих серед аналізованих країн. Це є однією із причин, які виправдовують різке підвищення у 2017 р. мінімальної заробітної плати в Україні. 
Серед інших причин визначено: невідповідність розміру мінімальної заробітної плати фактичному прожитковому мінімуму для працездатної особи; низька частка оплати праці у собівартості продукції; зниження частки оплати праці у структурі ВВП; високий рівень бідності серед працюючого населення та велика кількість отримувачів соціальних трансфертів серед населення.

Дослідження європейської практики визначення розміру мінімальної заробітної плати дало змогу виділити три підходи до цього процесу: на основі мінімальних потреб працівника, на основі розміру, який у 2-2,5 рази перевищує прожитковий мінімум та на основі встановлення співвідношення мінімальної і середньомісячної заробітної плати. В Україні визначення розміру мінімальної заробітної плати як однієї з основних соціальних гарантій здійснюється частково на основі об'єктивних показників соціально-економічного розвитку, не повною мірою враховуючи реальні потреби середньостатистичної української сім’ї, а частково на основі кон'юнктурних міркувань політичних сил.

До позитивних аспектів подвійного збільшення розміру мінімальної заробітної плати віднесено: наближення мінімальної заробітної плати до розміру фактичного прожиткового мінімуму; пожвавлення на ринку праці через посилення матеріальної зацікавленості працівників найпростіших професій та збільшення продуктивності праці; зменшення кількості отримувачів державної підтримки внаслідок збільшення їхніх доходів та виведення частини заробітної плати з «тіні» за умови належного контролю з боку відповідних органів.

Основними ризиками різкого підвищення заробітної плати є: збільшення безробіття, переведення частини працівників на неповний робочий день, можливе збільшення неформальної зайнятості. Серед недоліків аналізованого нововведення виділено зміну сутності поняття «мінімальна заробітна плата», що призвело до «зрівнялівки» в оплаті праці працівників 1-11 тарифного розрядів, і поспішність ухвалення такого рішення, що спричинило ефект «шокової терапії» для бізнесу і спонукало підприємців до коригування бізнес-планів в авральному режимі.

Для відновлення міжпосадових співвідношень необхідно привести прожитковий мінімум до фактичного його розміру і, використовуючи досвід країн $\mathrm{CC}$, установити законодавчу норму обов' язкового коригування основних державних соціальних стандартів і гарантій у сфері доходів відповідно до індексу інфляції у випадку підвищення споживчих цін більш як на $2 \%$.

Зменшити негативний вплив на рівень зайнятості населення можна лише за умови першочергового впровадження заходів зі стимулювання зайнятості населення, у першу чергу шляхом створення сприятливих умов для розвитку малого і середнього бізнесу. Використовуючи досвід європейських країн і враховуючи економічну ситуацію в Україні варто поступово переходити до формування мінімальної заробітної плати на основі встановлення розміру, який у 2-2,5 рази перевищує прожитковий мінімум. Проте найпершим кроком повинно стати узгодження розміру цього соціального стандарту з реаліями життя.

\section{ЛІТЕРАТУРА}

1. Про Стратегію сталого розвитку «Україна - 2020» [Електронний ресурс] : Указ Президента України № 5 від 12.01.2015. - Режим доступу: http://zakon3.rada.gov.ua/laws/show/5/2015

2. Дослідження проблем оплати праці: порівняльний аналіз (Україна та країни ЄС) : монографія / А.М. Колот, Г.Т. Куліков, О.М. Поплавська [та ін.] ; за заг. ред. А.М. Колота, Г.Т. Кулікова. - К. : KHEУ, 2008. - 274 c. 
3. Либанова Э. Государству выгодна дорогая рабочая сила / Э. Либанова // Бизнес. - 2007. № 43. - C. 22-24.

4. Мельниченко О.А. Мінімальна заробітна плата як засіб державного регулювання трудових доходів населення / О.А. Мельниченко, Р.М. Гулій // Публічне адміністрування: теорія та практика. - 2013. - Вип. 1. - Режим доступу: http://nbuv.gov.ua/UJRN/Patp_2013_1_7.

5. Kamińska A., Lewandowski P. The effects of minimum wage on a labour market with high temporary employment / Agnieszka Kamińska, Piotr Lewandowski, - 2015. - http://ibs.org.pl/app/uploads/ 2015/02/IBS_Working_Paper_07_2015.pdf. - Access mode (08.03.2017).

6. Schultena T. Minimum Wage Regimes in Europe / Thorsten Schulten/ - FES, 2014.- Режим доступу : http://library.fes.de/pdf-files/id-moe/10558.pdf . - Access mode (05.02.2017).

7. Minimum Wage Regulations in Selected European Countries / Lothar Funk, Hagen Lesch // Intereconomics. - 2006. - Access mode (08.03.2017). - Doi : 10.1007/s1027200601783

8. Про оплату праці: Закон України від 24.03.1995 № 108/95-ВР [Електронний ресурс]. - Режим доступу: http://zakon2.rada.gov.ua/laws/show/108/95-вр

9. Кодекс законів про працю України: Закон України від 10.12.1971 № 322-VIII [Електронний ресурс] [у редакції станом на 01.01.2017 p. ]. - Режим доступу : http://zakon3.rada.gov.ua/laws/ show/322-08

10. Конвенція Міжнародної організації праці № 131 про встановлення мінімальної заробітної плати з особливим урахуванням країн, що розвиваються: Міжнародний документ від 22.06.1970 № 131 (ратифіковано Законом України N 2997-IV від 19.10.2005р.) [Електронний ресурс]. - Режим доступу: http://zakon0.rada.gov.ua/laws/show/993_149

11. Лопушняк Г.С. Соціальні аспекти розвитку України / Лопушняк Г.С. Корелеська Є. // Финансы, учёт, банки: збірн. наук. пр. ДонНУ ім. В. Стуса. - Вінниця, 2016. - С. 21-33.

12. Statutory minimum wages in the EU 2016: Published on: 29 January 2016. / European Foundation for the Improvement of Living and Working Conditions. Режим доступу : https://www.eurofound.europa. eu/observatories/eurwork/articles/working-conditions-industrial-relations/statutory-minimum-wagesin-the-eu-2016 - Access mode (05.02.2017).

13. Gabor Kertei, Janos Kollo, Fighning «Low Equilibria» by Doubling the Minimum wage? Hungary's Experiment. - William Davidson, 2004. WP \#644. - Jan. 2004.- Режим доступу: https://deepblue. lib.umich.edu/bitstream/handle/2027.42/40030/wp644.pdf?sequence $=3$

14. Cross-Country Report on Minimum Wages : Selected Issues /IMF Country Report No. 16/151, 2016 International Monetary Fund - Access mode (05.02.2017). - http://www.imf.org/external/pubs/ft/ scr/2016/cr16151.pdf

15. Інфляційний звіт Національного банку України: Рішення Правління Національного банку України від 26 січня 2017 року № 48-рш «Про схвалення Інфляційного звіту» / Національний банк України (2017). - Режим доступу : https://bank.gov.ua/doccatalog/document?id=43401297 (Дата звернення 12 березня 2017 р.).

16. Ділові очікування підприємств України. IV квартал 2016 р.: результати чергового щоквартального опитування керівників підприємств щодо оцінки ними поточної та майбутньої ділової активності, інфляційних та курсових очікувань, змін економічної ситуації в країні./ Національний банк України (2016). - Режим доступу : https://bank.gov.ua/doccatalog/document?id=42352951 (Дата звернення 8 грудня 2016 р.)

17. Інформаційно-аналітичні матеріали на засідання НТСЕР до питання про стан реформування оплати праці / Федерація профспілок України. - К., 2014.- 32 с.

\section{REFERENCES}

1. Ukaz Prezydenta Ukrainy № 5 vid 12.01.2015 «Pro Stratehiiu staloho rozvytku «Ukraina - 2020» [Decree of the President of Ukraine of 12.01.2015 № 5 «About strategy for sustainable development «Ukraine - 2020»]. (2015, 12 January). zakon.rada.gov.ua Retrieved from http://zakon3.rada.gov. ua/laws/show/5/2015 [in Ukrainian].

2. Kolot, A.M., Kulikov, H.T., \& Poplavska, O.M. (2008). Doslidzhennia problem oplaty pratsi:porivnialnyi analiz (Ukraina ta krainy YeS) [Studies of the wage: comparative analysis (Ukraine and the EU)]. Kyiv : KNEU [in Ukrainian]. 
3. Libanova, E. (2007). Gosudarstvu vyigodna dorogaya rabochaya sila [The highly paid labor is favorable to the state]. Biznes - Biznes, 43, 22-24 [in Russian].

4. Melnychenko, O. A. \& Hulii, R. M. (2013). Minimalna zarobitna plata yak zasib derzhavnoho rehuliuvannia trudovykh dokhodiv naselennia [Minimum wage as way of state regulation of the labor income of the population]. Publichne administruvannia: teoriia ta praktyka - Public Administration: Theory and Practice, 1. Retrieved from http://nbuv.gov.ua/UJRN/Patp_2013_1_7 [in Ukrainian].

5. Kamińska, A. \& Lewandowski, P. (2015). The effects of minimum wage on a labour market with high temporary employment. ibs.org.pl Retrieved from http://ibs.org.pl/app/uploads/2015/02/IBS_ Working_Paper_07_2015.pdf [in Polish].

6. Schultena, T. (2014). Minimum Wage Regimes in Europe. FES. Retrieved from http://library.fes.de/pdffiles/id-moe/10558.pdf [in English].

7. Lothar, F., \& Hagen, L. (2006). Minimum Wage Regulations in Selected European Countries. Intereconomics.

8. Zakon Ukrainy «Pro oplatu pratsi» vid 24.03.1995 № 108/95-VR [The Law of Ukraine «On Remuneration of Labor» from 24.03.1995 №108/95-VR]. (1995, 24 March). zakon.rada.gov.ua. Retrieved from http://zakon2.rada.gov.ua/laws/show/108/95-вр [in Ukrainian].

9. Kodeks zakoniv pro pratsiu Ukrainy vid 10 hrudnia 1971 roku № 322-VIII [Labor Code of Ukraine on December 10, 1971 №322-VIII]. (1971, 10 December). zakon.rada.gov.ua. Retrieved from http:// zakon3.rada.gov.ua/laws/show/322-08 [in Ukrainian].

10. Konventsiia Mizhnarodnoi orhanizatsii pratsi N 131 pro vstanovlennia minimalnoi zarobitnoi platy z osoblyvym urakhuvanniam krain, shcho rozvyvaiutsia. Ratyfikovano Zakonom Ukrainy N 2997-IV ( 2997-15 ) vid 19.10.2005 [ILO Convention N 131 on Minimum Wage Fixing developing countries. Ratified by Law of Ukraine N 2997-IV (2997-15) of 19.10.2005]. (2005, 19 October). zakon.rada.gov.ua. Retrieved from http://zakon0.rada.gov.ua/laws/show/993_149 [in Ukrainian].

11. Lopushniak, H. \& Koreleska, Ye. (2016). Sotsialni aspekty rozvytku Ukrainy [Social aspects of development of Ukraine]. Finansyi, uchyot, banki - Finance, accounting, banks, 21-33. Vinnitsa [in Ukrainian].

12. European Foundation for the Improvement of Living and Working Conditions. (2016). Statutory minimum wages in the EU 2016. eurofound.europa.eu. Retrieved from https://www.eurofound.europa.eu/ observatories/eurwork/articles/working-conditions-industrial-relations/statutory-minimum-wagesin-the-eu-2016 [in English].

13. Gabor, K., \& Kollo, J. (2004). Fighning «Low Equilibria» by Doubling the Minimum wage? Hungary's Experiment. William Davidson Institute Working Papers Series. William Davidson Institute at the University of Michigan. Retrieved from https://deepblue.lib.umich.edu/bitstream/handle/2027.42/ 40030/wp644.pdf?sequence $=3$ [in English]

14. International Monetary Fund (2016). Cross-Country Report on Minimum Wages: Selected Issues. Retrieved from http://www.imf.org/external/pubs/ft/scr/2016/cr16151.pdf [in English].

15. Infliatsiinyi zvit Natsionalnoho banku Ukrainy [The Inflation Report of the National Bank of Ukraine]. (2017). The National Bank of Ukraine. bank.gov.ua. Retrieved from https://bank.gov.ua/doccatalog/ document?id=43401297 [in Ukrainian].

16. Dilovi ochikuvannia pidpryiemstv Ukrainy. IV kvartal 2016 r.: rezultaty cherhovoho shchokvartalnoho opytuvannia kerivnykiv pidpryiemstv shchodo otsinky nymy potochnoi ta maibutnoi dilovoi aktyvnosti, infliatsiinykh ta kursovykh ochikuvan, zmin ekonomichnoi sytuatsii v kraini. [Business expectations of the enterprises in Ukraine. 2016, IV quarter: results of the regular quarterly survey of business leaders to assess the current and future business activity, inflation and exchange rate expectations, changes in economic situation]. (2016). The National Bank of Ukraine. bank.gov.ua. Retrieved from https://bank. gov.ua/doccatalog/document?id=42352951 [in Ukrainian].

17. Informatsiino-analitychni materialy na zasidannia NTSER do pytannia pro stan reformuvannia oplaty pratsi [Informational and analytical materials on the meeting NTSEC to the situation of wage reform]. (2014). Federation of Trade Unions of Ukraine. Kyiv [in Ukrainian].

Стаття надішла до редакції 20.03.2017. 